\title{
Preparation and mechanical properties of PCL-based polyurethanes as potential biomaterials for short-term applications
}

\author{
Marcin Sobczak, ${ }^{1^{*}}$ Cezary Dębek, ${ }^{2}$ Piotr Goś ${ }^{1}$ \\ ${ }^{1 *}$ Medical University of Warsaw, Faculty of Pharmacy, Department of Inorganic and \\ Analytical Chemistry, ul. Banacha 1, 02-097 Warsaw, Poland; e-mail: \\ marcin.sobczak@wp.pl, marcin.sobczak@wum.edu.pl. \\ 2 Institute for Engineering of Polymer Materials and Dies, ul. Marii Skłodowskiej-Curie \\ 55, 87-100 Toruń, Poland.
}

(Received: 01 September, 2010; published: 28 December, 2010)

\begin{abstract}
A series of polyurethanes (PURs) were prepared by metal-free method, containing polycaprolactone (PCL) as the soft segment with molecular weights of 1600,2400 and 2600 . PCL was obtained by the ring-opening polymerization of $\varepsilon$ caprolactone in the presence L-alanine and L-phenyloalanine. The structure of synthesized oligoesters and PURs were spectroscopically confirmed. The molecular weights, mechanical and thermal properties of the obtained materials were reported.
\end{abstract}

\section{Introduction}

Polyurethanes (PURs) are very interesting materials which characterize unique combination of biological, chemical and physical properties. They have good mechanical properties, good biocompatibility, biostability and antithrombogenicity. PURs have been used as biomaterials in various applications (e.g. aortic grafts, endotracheal tubes, vascular tubing, heart valves, heart assist devices, catheters, pacemaker wire insulation, transcutaneous access sets, restorative and preventative dental materials, components of hemodialysis units). [1-8]

The commercial PURs are obtained on the polyaddition process which involves diisocyanates and bi-functional or multi-functional polyols (polyethers, polyesters, polycarbonates) with hydroxyl terminal group. The catalytic activity in the reaction of isocyanates with polyols is shown by organometallic compounds ( $\mathrm{Sn}, \mathrm{Pb}$ and $\mathrm{Fe}$ ). [9]

Linear poly( $\varepsilon$-caprolactone) (PCL) is often used in the biomedical PURs production processes. They are usually prepared by ring-opening polymerization (ROP) in the presence of alkaline, Lewis acids, enzymes and coordination catalysts [10-19]. The coordinating catalysts are very effective in ROP of $\varepsilon$-caprolactone (CL) but most of them are toxic for humans. Recently, we found that amino acids and creatinine, are satisfactory natural initiators for ROP of cyclic esters [20-21].

Our objective in this study was to synthesize and characterize a group of PURs based on PCL. We describe method of the synthesis of PURs without using metalcatalysts. The preliminary studies on their mechanical properties were shown. We believe that the obtained polyurethanes can find practical applications as 
biomaterials for short-term applications (e.g. catheters, cardiovascular, wound dressing, transdermal patches).

\section{Results and discussion}

\section{Synthesis of PCL}

Recent investigation shows that natural amino acids are satisfactory initiators for ROP of cyclic esters [20]. So, we decided to carry out more detailed investigation of that reaction initiated by $\mathrm{L}$-alanine and L-phenylalanine. The purpose of this work was to obtain the oligomers with respect to their applications as soft segments in biomedical polyurethanes.

The polymerization reactions of $\mathrm{CL}$ were carried out at $140{ }^{\circ} \mathrm{C}$ for $2-72 \mathrm{~h}$ (Scheme 1 ). The molar ratio of amino acids to a given monomer was 1:25, 1:50 or 1:100. Reaction conditions, yields, intrinsic viscosity and average molecular weight of polyesters are collected in Table 1.
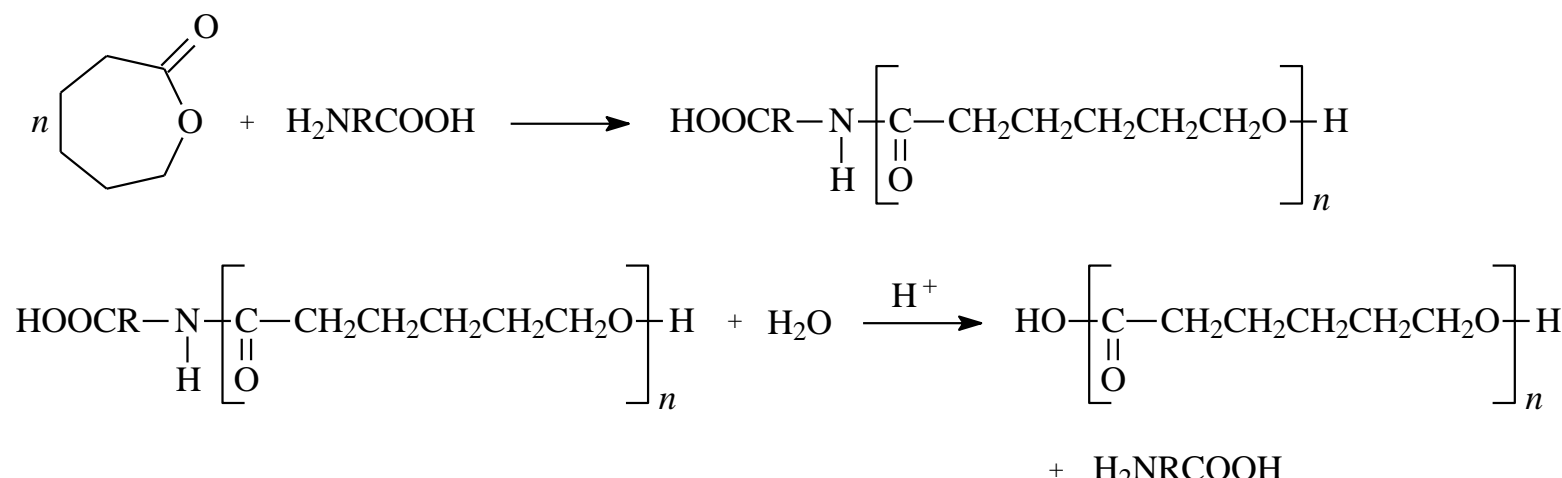

$\mathrm{R}$ - Ala or Phe unit

Scheme 1. Synthesis of PCL.

The chemical structures of the obtained oligoesters were confirmed by ${ }^{13} \mathrm{C},{ }^{1} \mathrm{H}-\mathrm{NMR}$ and IR studies (see experimental section). Insertion of the amino acids fragment into the polymer chain was confirmed by the proton NMR spectral analysis. The peaks at 5.8 - $6.2 \mathrm{ppm}$ were observed in all products obtained by polymerization of CL. The formation of the -NHCO- group indicates that the amino group of the amino acids was incorporated into PCL chain [20]. The peaks characteristic for amino acids fragment were not observed in the spectra of purified polymerization products (after precipitated from cold methanol with diluted hydrochloric acid). The disappearance of the peaks at $5.8-6.2 \mathrm{ppm}$ indicated that the amide group in the polymers was removed completely before purification process.

The MALDI-TOF spectra of PCL comprise three of peaks. The most prominent series of peaks is characterized by a mass increment of $114 \mathrm{Da}$, which is equal to the mass of the repeating unit in the PCL. It is assigned to PCL terminated with a hydroxyl group (residual mass: $41 \mathrm{Da}, \mathrm{Na}^{+}$adduct). The second series of peaks also corresponded to PCL, terminated with a hydroxyl group (residual mass: $57 \mathrm{Da}, \mathrm{K}^{+}$ adduct). In addition, the mass spectrum contains a low-intensity series of peaks corresponding to cyclic molecules (residual mass: $23 \mathrm{Da}, \mathrm{Na}^{+}$adduct). The content of macrocycles was estimated on the basis of the intensity ratio of the peaks for linear 
and cyclic polymer. MALDI-TOF spectrum shows the formation of cyclic species, as a consequence of backbiting degradation. This feature is observed for all amino acids studied [20].

Tab. 1. Polymerization of CL initiated by L-Ala and L-Phe at $140{ }^{\circ} \mathrm{C}$.

\begin{tabular}{cccccccccccc}
\hline Code & $\mathrm{I}$ & $\mathrm{M} / \mathrm{I}$ & $\begin{array}{c}\text { Time } \\
(\mathrm{h})\end{array}$ & $\begin{array}{c}\text { Yield } \\
(\%)\end{array}$ & $\begin{array}{c}M_{n}{ }^{a} \\
(\mathrm{Da})\end{array}$ & $M_{w} / M_{n}{ }^{a}$ & $\begin{array}{c}M_{n}^{b} \\
(\mathrm{Da})\end{array}$ & $M_{w} / M_{n}^{b}$ & $\begin{array}{c}\mathrm{MC} \\
(\mathrm{mol} \%)\end{array}$ & $\begin{array}{c}\eta_{\text {inh }}{ }^{c} \\
\left(\mathrm{dll} \cdot \mathrm{g}^{-1}\right)\end{array}$ & $\begin{array}{c}M_{n}{ }^{d} \\
(\mathrm{Da})\end{array}$ \\
\hline PCL-1 & L-Ala & $25: 1$ & 24 & 76 & - & - & - & - & - & 0.06 & - \\
PCL-2 & L-Ala & $25: 1$ & 48 & 82 & 1900 & 1.2 & 1800 & 1.1 & 9 & 0.06 & 1600 \\
PCL-3 & L-Ala & $50: 1$ & 2 & traces & - & - & - & - & - & - & - \\
PCL-4 & L-Ala & $50: 1$ & 24 & 74 & - & - & 2200 & 1.1 & 5 & 0.11 & - \\
PCL-5 & L-Ala & $50: 1$ & 48 & 80 & 3300 & 1.2 & 2400 & 1.2 & 8 & 0.12 & 2600 \\
PCL-6 & L-Ala & $50: 1$ & 72 & 82 & - & - & 2500 & 1.2 & 21 & 0.12 & - \\
PCL-7 & L-Ala & $100: 1$ & 24 & 79 & 4400 & 1.3 & - & - & - & 0.21 & - \\
PCL-8 & L-Ala & $100: 1$ & 48 & 90 & - & - & - & - & - & 0.23 & - \\
PCL-9 & L-Phe & $25: 1$ & 24 & 84 & - & - & - & - & - & 0.07 & - \\
PCL-10 & L-Phe & $25: 1$ & 48 & 88 & - & - & - & - & - & 0.07 & - \\
PCL-11 & L-Phe & $50: 1$ & 24 & 81 & - & - & - & - & - & 0.12 & - \\
PCL-12 & L-Phe & $50: 1$ & 48 & 85 & 2900 & 1.2 & 2000 & 1.2 & 6 & 0.13 & 2400 \\
PCL-13 & L-Phe & $100: 1$ & 24 & 89 & - & - & - & - & - & 0.27 & - \\
PCL-14 & L-Phe & $100: 1$ & 48 & 88 & 3800 & 1.3 & - & - & - & 0.24 & - \\
\hline
\end{tabular}

I - initiator, M/I - ratio of monomer to initiator,

$M_{n}^{a}, M_{w} / M_{n}^{a}$ - molecular mass and polydispersity of oligomers determined by GPC;

$M_{n}^{b}, M_{w} / M_{n}^{b}$ - molecular mass and polydispersity of oligomers determined by MALDI;

$\mathrm{MC}$ - macrocycles content (determined by MALDI-TOF)

${ }^{\mathrm{C}}$ measured at $30{ }^{\circ} \mathrm{C}$ in DMF;

${ }^{d} M_{n}$ calculated from $L_{O H}$

Spectroscopy and spectrometry studies have been in agreement with earlier findings [20].

The average molecular mass values of PCL determined by the MALDI-TOF method are in the 1800-2500 Da range (polydispersity indexes 1.1-1.2).

The effects of reaction conditions such as time and ratio of monomer to initiator are described below.

Tab. 2. Synthesis of PURs.

\begin{tabular}{lccccc}
\hline Code & Reagents/catalyst & Molar ratio & $\begin{array}{c}\eta_{i h n}{ }^{a} \\
(\mathrm{dL} / \mathrm{g})\end{array}$ & $\begin{array}{c}T_{g}{ }^{b} \\
{\left[{ }^{\circ} \mathrm{C}\right]}\end{array}$ & $\begin{array}{c}T_{m}{ }^{c} \\
{\left[{ }^{\circ} \mathrm{C}\right]}\end{array}$ \\
\hline PUR-1 & MDI-1,4-BD -OEAD-PCL-2/DABCO & $2.5: 1.5: 0.6: 0.4: 0.01$ & 1.81 & -12 & 74 \\
PUR-2 & MDI-1,4-BD -OEAD-PCL-5/DABCO & $2.5: 1.5: 0.6: 0.4: 0.01$ & 2.24 & -14 & 68 \\
PUR-3 & MDI-1,4-BD -OEAD-PCL-5/DABCO & $2.5: 1.0: 0.8: 0.7: 0.01$ & 2.04 & -17 & 55 \\
PUR-4 & MDI-1,4-BD -OEAD-PCL-5/DABCO & $2.5: 0.7: 1: 0.8: 0.01$ & 1.93 & -18 & 42 \\
PUR-5 & MDI-1,4-BD -OEAD-PCL-12/DABCO & $2.5: 1.5: 0.6: 0.4: 0.01$ & 1.98 & -15 & 68 \\
PUR-6 & MDI-1,4-BD -OEAD-PCL-12/DABCO & $2.5: 0.7: 1: 0.8: 0.01$ & 2.03 & -19 & 44 \\
\hline${ }^{a}$ measured at 30 ${ }^{\circ} \mathrm{C}$ in DMF; \\
blass transition temperature determined from DCS (the second heating) & & &
\end{tabular}


Polymerization yields were similar and practically independent of the nature of the amino acid and ratio of monomer to initiator (see Tab. 1). The reaction yield was determined by the weight method. For PCL-2, PCL-5, PCL-8, PCL-10, PCL-12 and PCL-14 the corresponding monomer yield values were $82 \%, 80 \%, 90 \%, 88 \%, 85 \%$ and $88 \%$, respectively. Similarly, the yield values for PCL-1, PCL-4, PCL-7, PCL-9, PCL-11 and PCL-13 were $76 \%, 74 \%, 79 \%, 84 \%, 81 \%$ and $89 \%$, respectively.

Table 1 shows the yield of polymerization of $\mathrm{CL}$ versus time. After $2 \mathrm{~h}$ of conducting the polymerization of $\mathrm{CL}$, traces of the product were only obtained. However, after 24,48 and $72 \mathrm{~h}$ the reaction yield was 74,80 and $82 \%$, respectively. The decrease in polymerization rate as the polymerization proceeds is consistent with slowed diffusion of monomer and propagating chain ends with increased reaction viscosity, probably.

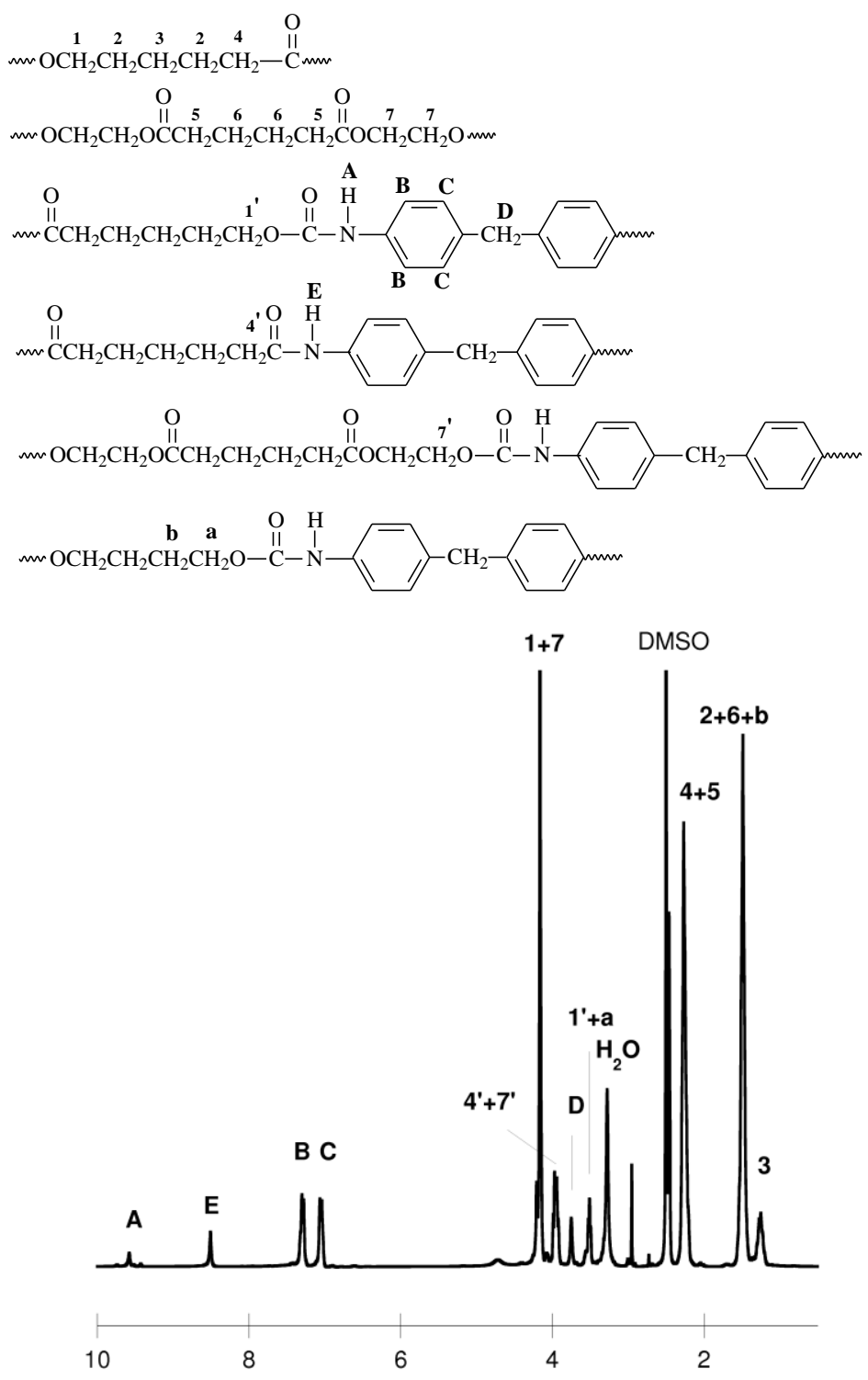

Fig. 1. The ${ }^{1} \mathrm{H}-\mathrm{NMR}$ spectrum of the PCL-based PUR (in DMSO- $\mathrm{d}_{6}$ ).

However, significant differences were observed between the intrinsic viscosities (see Tab. 1). As shown in Table 1, the PCL products were obtained with the intrinsic 
viscosity of $0.06,0.12,0.23,0.07,0.13$ and $0.24 \mathrm{dl} \cdot \mathrm{g}^{-1}$ for PCL-2, PCL-5, PCL-8, PCL-10, PCL-12 and PCL-14, respectively.

The average molecular mass values of PCL determined by the GPC method are in the 1900-4400 Da range. The polydispersity shows only small variations (between 1.2 and 1.3). As shown, the molecular mass of PCL is dependent on the monomer/amino acid molar ratio.

\section{Synthesis of polyurethanes}

Polyurethanes (PURs) were synthesized using PCL and OEAD as a soft segment and $\mathrm{MDI}$ and $\mathrm{BD}$ as components of the hard segment. DABCO was the polyaddition catalysts. A one-step melt polymerization procedure was employed (at the molar ratio of $\mathrm{NCO} / \mathrm{OH}=1$ ). The reaction conditions and $\eta_{\text {inh }}$ of the products obtained are listed in Table 2.
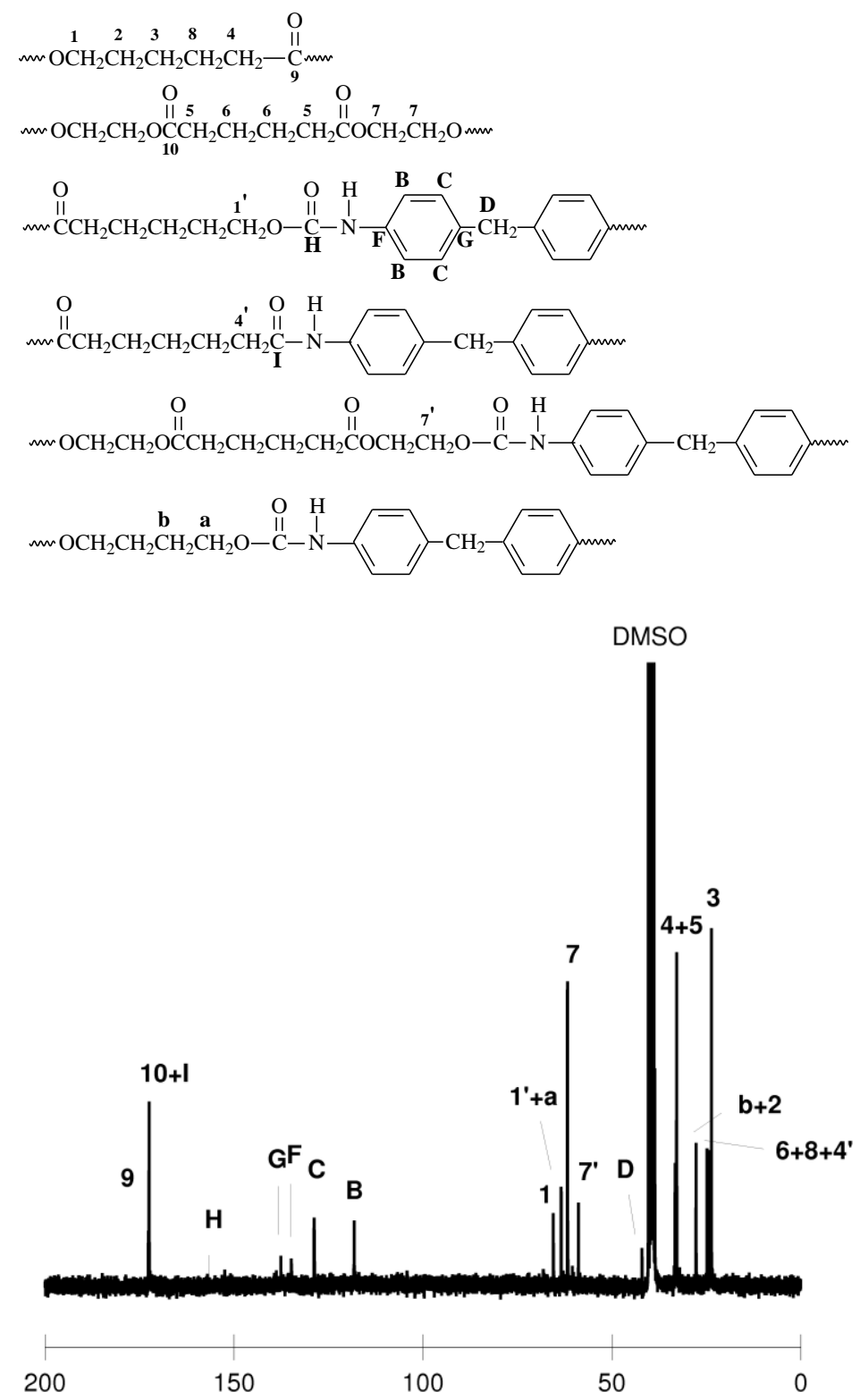

Fig. 2. The ${ }^{13} \mathrm{C}-\mathrm{NMR}$ spectrum of the PCL-based PUR (in DMSO- $\mathrm{d}_{6}$ ). 
The chemical structure of PURs was characterized by ${ }^{1} \mathrm{H},{ }^{13} \mathrm{C}$ NMR and FT-IR (Figs. 1 and 2). The data was shown in the experimental section. It was found that all the characteristic peaks and absorption bands belonging to MDI, BD, PCL and OADE existed in the spectra of PURs. It indicated the reactions were complete and PURs were formed.

DSC results for the PURs during the second heating run are summarized in Table 2. The $T_{g}$ values lie in the -12 to $-19^{\circ} \mathrm{C}$. Next, the melting point of crystalline phase values lie in the 42 to $74{ }^{\circ} \mathrm{C}$.

Tab. 3. Mechanical properties of the obtained PURs based on PCL.

\begin{tabular}{llllllr}
\hline Code & $\begin{array}{l}\mathrm{Se}_{f} \\
{[\mathrm{MPa}]}\end{array}$ & $\begin{array}{l}\mathrm{Se}_{100} \\
{[\mathrm{MPa}]}\end{array}$ & $\begin{array}{l}\mathrm{Se}_{200} \\
{[\mathrm{MPa}]}\end{array}$ & $\begin{array}{l}\mathrm{Se}_{300} \\
{[\mathrm{MPa}]}\end{array}$ & $\begin{array}{l}\mathrm{E}_{\mathrm{b}} \\
{[\%]}\end{array}$ & {$[\mathrm{olRH}]$} \\
\hline PUR-1 & $27.0 \pm 1.1$ & $6.7 \pm 0.2$ & $7.0 \pm 0.1$ & $10.1 \pm 0.3$ & $318 \pm 8$ & $51 \pm 2$ \\
PUR-2 & $29.0 \pm 1.0$ & $6.5 \pm 0.2$ & $7.2 \pm 0.2$ & $10.3 \pm 0.4$ & $301 \pm 7$ & $53 \pm 2$ \\
PUR-3 & $20.3 \pm 0.8$ & $7.4 \pm 0.2$ & $8.8 \pm 0.2$ & $12.7 \pm 0.4$ & $435 \pm 8$ & $42 \pm 2$ \\
PUR-4 & $18.3 \pm 0.7$ & $7.7 \pm 0.2$ & $9.1 \pm 0.2$ & $13.1 \pm 0.4$ & $455 \pm 10$ & $39 \pm 1$ \\
PUR-5 & $26.1 \pm 0.8$ & $6.6 \pm 0.1$ & $7.9 \pm 0.2$ & $11.4 \pm 0.3$ & $329 \pm 7$ & $48 \pm 2$ \\
PUR-6 & $20.1 \pm 0.6$ & $7.9 \pm 0.1$ & $8.9 \pm 0.2$ & $14.1 \pm 0.3$ & $477 \pm 11$ & $40 \pm 2$ \\
\hline
\end{tabular}

$\mathrm{Se}_{\mathrm{f}}$ - fail stress, $\mathrm{Se}_{100}-$ stress at $100 \%$ elongation, $\mathrm{Se}_{200}-$ stress at $200 \%$ elongation, $\mathrm{Se}_{300}-$ stress at $300 \%$ elongation, $\mathrm{E}_{\mathrm{b}}$ - elongation at break, olRH - hardness

Mechanical properties of PURs are more important than any other properties with respect to practical applications. So, some mechanical properties like fail stress $\left(\mathrm{Se}_{\mathrm{f}}\right)$, stress at $100 \%$ elongation $\left(\mathrm{Se}_{100}\right)$, stress at $200 \%$ elongation $\left(\mathrm{Se}_{200}\right)$, stress at $300 \%$ elongation $\left(\mathrm{Se}_{300}\right)$, hardness $(\mathrm{olRH})$ and stress at $100 \%$ elongation at break $\left(\mathrm{E}_{\mathrm{b}}\right)$ of PURs obtained are determined. The data on the tensile analysis of PURs with various soft segment contents were listed in Table 3 . It can be seen that the PURs have high fail stress and hardness, and their elongation at break can be greater than $300 \%$. The elongation at break decreases with a significant decrease in the soft segment. It was found that PUR-4 and PUR-3 have better elongations with more than $400 \%$ while PUR-2 showed an elongation of about $300 \%$. Similarly, $E_{b}$ for PUR6 and PUR-5 was $477 \%$ and $329 \%$, respectively. The fail stress showed an opposite trend. For example, $\mathrm{Se}_{\mathrm{f}}$ for PUR-2, PUR-3 and PUR-4 was 29 and 20 and $18 \mathrm{MPa}$, respectively. Similarly, PUR-5 has better fail stress than PUR-6.

It is seen that the fail stress and the hardness increase with increasing the hardsegment content, and the elongation at break has the opposite trend.

The toxicity of obtained PCL-based PURs is still under study and will be presented in the next paper.

\section{Conclusions}

Series of oligoesters have been synthesized by ring-opening polymerization of CL in the presence of L-Ala and L-Phe with high yields (about $90 \%$ ). The oligoesters were reacted with 4,4'-methylenebis(phenyl isocyanate) in the presence of 1,4-butanediol as the chain extender to obtain PURs. The polyaddition process was catalyzed by DABCO. Obtained materials characterized good mechanical properties (fail stress, hardness and elongation at break). Values between 16 and $30 \mathrm{MPa}, 39$ and 53, 300 and $400 \%$ were found for these properties, respectively. PURs showed elastomeric 
properties. The study of the toxicity and the blood compatibility of obtained PURs are further carried out. The free-metal method of the synthesis of oligomeroles and PURs is very promising in the synthesis of polymers intended for biomedical applications.

\section{Experimental part}

\section{Materials}

$\varepsilon$-Caprolactone (2-Oxepanone, 99\%, CL) was purchased from Aldrich. Before use, it was dried and distilled over $\mathrm{CaH}_{2}$ at reduced pressure. Amino acids (99\%, Aldrich) (L-alanine - L-Ala, L-phenylalanine - L-Phe), dichloromethane (POCh), dimethyl sulfoxide (DMSO, 99\%, Aldrich), N,N-dimethylformamide (DMF, 99\%, Aldrich), methanol (POCh) were used as received. 4,4'-methylenebis(phenyl isocyanate) (MDI, 98\%, Aldrich), dihydroxy(polyethylene adipate) (OEAD, $\mathrm{M}_{\mathrm{n}}=1000 \mathrm{Da}$, Aldrich), 1,4-butanediol (BD, 98\%, Fluka), 1,4-diazabicyclo[2.2.2]octane (DABCO, 99\%, Aldrich) were used without further purification.

\section{Synthesis of PCL}

$\mathrm{CL}$ and amino acids (L-Ala, L-Phe) were placed in glass ampoules under argon atmosphere. The reaction vessels were then left standing in a thermostated oil bath for the required temperature and time. When the reaction was completed (Table 1), the cold product was dissolved in dichloromethane, precipitated from cold methanol with diluted hydrochloric acid (5\% aqueous solution) and dried in vacuum for $72 \mathrm{~h}$ to isolate a powdery polymer.

\section{$P C L$ :}

${ }^{1} \mathrm{H}$ NMR $\left(\mathrm{CDCl}_{3}, \delta, \mathrm{ppm}\right): 4.03\left(2 \mathrm{H}, \mathrm{t},-\mathrm{CH}_{2} \mathrm{CH}_{2} \mathrm{OC}(\mathrm{O})-\right), 3.70\left(2 \mathrm{H}, \mathrm{t},-\mathrm{CH}_{2} \mathrm{CH}_{2} \mathrm{OH}\right.$, end group), 2.27 (2H, t, $\left.-\mathrm{CH}_{2} \mathrm{CH}_{2} \mathrm{COO}-\right), 1.61\left(4 \mathrm{H}, \mathrm{m},-\mathrm{CH}_{2} \mathrm{CH}_{2} \mathrm{COO}-\right), 1.36(2 \mathrm{H}, \mathrm{m}$, $\left.\mathrm{CH}_{2} \mathrm{CH}_{2} \mathrm{CH}_{2} \mathrm{CH}_{2} \mathrm{CH}_{2-}\right) ;{ }^{13} \mathrm{C} N M R\left(\mathrm{CDCl}_{3}, \delta, \quad \mathrm{ppm}\right): 173.3(-\mathrm{C}(\mathrm{O}) \mathrm{O}-), 63.9$ ($\left.\mathrm{CH}_{2} \mathrm{CH}_{2} \mathrm{OC}(\mathrm{O})-\right)$, 33.8 (- $\left.\mathrm{CH}_{2} \mathrm{CH}_{2} \mathrm{COO}-\right)$, 28.1 (- $\left.\mathrm{CH}_{2} \mathrm{CH}_{2} \mathrm{OC}(\mathrm{O})-\right)$, $25.4\left(-\mathrm{CH}_{2} \mathrm{CH}_{2} \mathrm{COO}-\right.$ ), $24.4\left(-\mathrm{CH}_{2} \mathrm{CH}_{2} \mathrm{CH}_{2} \mathrm{CH}_{2} \mathrm{CH}_{2}-\right)$; FTIR $\left(\mathrm{KBr}, \mathrm{cm}^{-1}\right): 2950\left(\mathrm{U}_{\mathrm{as}} \mathrm{CH}_{2}\right), 2865\left(\mathrm{U}_{\mathrm{s}} \mathrm{CH}_{2}\right), 1730$ (uC=O), 1240 ( $\left.\mathrm{u}_{\mathrm{as}} \mathrm{COC}\right), 1190$ (uOC-O), 1170 (us $\left.\mathrm{COC}\right)$.

\section{Synthesis of PURs}

All the PURs were synthesized by a one-step melt polymerization. Before reaction all reactants e.g. MDI, OEAD, BD and $P C L$ were dried in vacuum for $1 \mathrm{~h}$ at $70{ }^{\circ} \mathrm{C}$. Then the polyesters (OEAD and PCL), BD and DABCO were mixed at $100^{\circ} \mathrm{C}$ in a $250-\mathrm{ml}$ three-necked flask equipped with a stirrer and thermometer. After $1 \mathrm{~h}$ MDI was progressively added into the reactor and content of the flask was vigorously stirred. The synthesis of PUR was carried out under argon atmosphere at the $\mathrm{NCO} / \mathrm{OH}$ molar ratio of 1 . After the reaction was complete, the product was conditioned in a steel mould under vacuum at $35{ }^{\circ} \mathrm{C}$ for $2 \mathrm{~h}$. The PURs were dissolved in DMSO and then isolated from the solution by pouring into water. Then, they were kept under vacuum at $70{ }^{\circ} \mathrm{C}$ for one week.

PURs:

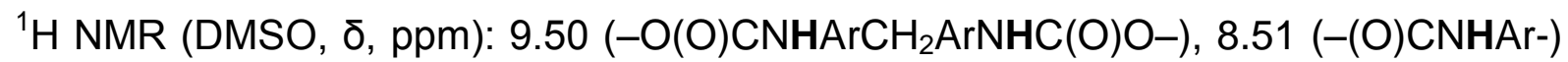
7.31 (hydrogen atoms attached to aromatic carbon), 7.04 (hydrogen atoms attached to aromatic carbon), $4.15\left(-\mathrm{OC}(\mathrm{O}) \mathrm{CH}_{2} \mathrm{CH}_{2} \mathrm{CH}_{2} \mathrm{CH}_{2} \mathrm{C}(\mathrm{O}) \mathrm{OCH}_{2} \mathrm{CH}_{2} \mathrm{OC}(\mathrm{O}) \mathrm{NHAr}-\right)$, ($\left.\mathrm{OC}(\mathrm{O}) \mathrm{NHAr}-\mathrm{OCH}_{2} \mathrm{CH}_{2} \mathrm{CH}_{2} \mathrm{CH}_{2} \mathrm{CH}_{2} \mathrm{C}(\mathrm{O}) \mathrm{O}-\right)$, (-ArHNC(O)OCH $\mathrm{CH}_{2} \mathrm{CH}_{2} \mathrm{CH}_{2} \mathrm{OC}(\mathrm{O}) \mathrm{NH}$ 
Ar-), (- $\left.\mathrm{OCH}_{2} \mathrm{CH}_{2} \mathrm{CH}_{2} \mathrm{CH}_{2} \mathrm{CH}_{2} \mathrm{C}(\mathrm{O}) \mathrm{O}-\right)$, 3.78 (-O(O) $\left.\mathrm{CNHArCH}_{2} \mathrm{ArNHC}(\mathrm{O}) \mathrm{O}-\right)$, 2.35 ($\left.\mathrm{OCH}_{2} \mathrm{CH}_{2} \mathrm{CH}_{2} \mathrm{CH}_{2} \mathrm{CH}_{2} \mathrm{C}(\mathrm{O}) \mathrm{O}-\right)$, 1.81 (-ArHN(O) $\mathrm{COCH}_{2} \mathrm{CH}_{2} \mathrm{CH}_{2} \mathrm{CH}_{2} \mathrm{OC}(\mathrm{O}) \mathrm{NHAr}-$ ), $1.54\left(-\mathrm{OCH}_{2} \mathrm{CH}_{2} \mathrm{CH}_{2} \mathrm{CH}_{2} \mathrm{CH}_{2} \mathrm{C}(\mathrm{O}) \mathrm{O}-\right), \quad 1.34 \quad\left(-\mathrm{OCH}_{2} \mathrm{CH}_{2} \mathrm{CH}_{2} \mathrm{CH}_{2} \mathrm{CH}_{2} \mathrm{C}(\mathrm{O}) \mathrm{O}-\right) ;{ }^{13} \mathrm{C}$ NMR $\left(\mathrm{CDCl}_{3}, \delta, \mathrm{ppm}\right): 172.5-170.0\left(-\mathrm{OC}(\mathrm{O})-, 154.6\left(-\mathrm{OCH}_{2} \mathrm{CH}_{2} \mathrm{CH}_{2} \mathrm{CH}_{2} \mathrm{OC}(\mathrm{O}) \mathrm{NH}\right.\right.$ Ar-, $153.3\left(-\mathrm{OC}(\mathrm{O}) \mathrm{CH}_{2} \mathrm{CH}_{2} \mathrm{CH}_{2} \mathrm{CH}_{2} \mathrm{C}(\mathrm{O}) \mathrm{OCH}_{2} \mathrm{CH}_{2} \mathrm{OC}(\mathrm{O}) \mathrm{NHAr}-\right.$ ), 137.1 (aromatic carbon atoms - bonded with the methylene group), 135.4 (aromatic carbon atoms bonded with the urethane group), 128.8 (aromatic carbon atoms), 118.3 (aromatic carbon atoms), $\left.63.0-\mathrm{OCH}_{2} \mathrm{CH}_{2} \mathrm{CH}_{2} \mathrm{CH}_{2} \mathrm{CH}_{2} \mathrm{OC}(\mathrm{O}) \mathrm{NHAr}-\right)$ (-ArNH $\left.\mathrm{C}(\mathrm{O}) \mathrm{OCH}_{2} \mathrm{CH}_{2} \mathrm{CH}_{2} \mathrm{CH}_{2} \mathrm{OC}(\mathrm{O}) \mathrm{NHAr}-\right), \quad 61.8-\mathrm{OCH}_{2} \mathrm{CH}_{2} \mathrm{CH}_{2} \mathrm{CH}_{2} \mathrm{C}(\mathrm{O}) \mathrm{OCH}_{2} \mathrm{CH}_{2} \mathrm{O}$ $\mathrm{C}(\mathrm{O}) \mathrm{NHAr}-)$, $32.9 \quad\left(-\mathrm{OCH}_{2} \mathrm{CH}_{2} \mathrm{CH}_{2} \mathrm{CH}_{2} \mathrm{CH}_{2} \mathrm{C}(\mathrm{O}) \mathrm{O}-, \quad 25.3 \quad\left(-\mathrm{OCH}_{2} \mathrm{CH}_{2} \mathrm{CH}_{2} \mathrm{CH}_{2}\right.\right.$ $\left.\mathrm{CH}_{2} \mathrm{C}(\mathrm{O}) \mathrm{O}-\right)$, $23.7\left(-\mathrm{OCH}_{2} \mathrm{CH}_{2} \mathrm{CH}_{2} \mathrm{CH}_{2} \mathrm{CH}_{2} \mathrm{C}(\mathrm{O}) \mathrm{O}-\right)$ (-ArNHC(O)OCH $\mathrm{CH}_{2} \mathrm{CH}_{2} \mathrm{CH}_{2} \mathrm{O}$ $\mathrm{C}(\mathrm{O}) \mathrm{NHAr}-)$, $22.5\left(-\mathrm{OCH}_{2} \mathrm{CH}_{2} \mathrm{CH}_{2} \mathrm{CH}_{2} \mathrm{CH}_{2} \mathrm{C}(\mathrm{O}) \mathrm{O}-\right)$, 17.6 (-OCH$\left.\left(\mathrm{CH}_{3}\right) \mathrm{C}(\mathrm{O}) \mathrm{O}-\right)$; FTIR $\left(\mathrm{KBr}, \mathrm{cm}^{-1}\right): 3340$ ( $\mathrm{N}-\mathrm{H}$ in urethane group), 2990-2945 (C-H in $-\mathrm{CH}_{2}-$ group), 28802860 ( $\mathrm{C}-\mathrm{H}$ in $-\mathrm{CH}_{3}$ and $-\mathrm{CH}$ - group), 1750-1690 (-C=O in urethane group), 1720 ($\mathrm{C}=\mathrm{O}$ in ester group), $1600\left(\mathrm{C}-\mathrm{H}\right.$ in $\left.-\mathrm{C}_{6} \mathrm{H}_{4}\right), 1250$ (C-O in $-\mathrm{C}(\mathrm{O}) \mathrm{O}-$ group).

\section{Measurements}

The polymerization products were characterized by means of ${ }^{1} \mathrm{H}$ and ${ }^{13} \mathrm{C}-\mathrm{NMR}$ (Varian $300 \mathrm{MHz}$ ), and FT-IR spectroscopy (Perkin-Elmer). The NMR spectra were recorded in $\mathrm{CDCl}_{3}$. The IR spectra were measured from $\mathrm{KBr}$ pellets. Relative molecular mass and molecular mass distributions were determined by MALDI-TOF and gel permeation chromatography (GPC) techniques. MALDI-TOF spectra were measured in the linear mode on a Kompact MALDI 4 Kratos analytical spectrometer using a nitrogen gas laser and 2[(4hydroxyphenyl)diazenyl] benzoic acid (HABA) as a matrix. Molecular weight and molecular weight distributions of polymers were determined at $308 \mathrm{~K}$ on Lab Alliance gel permeation chromatography equipped with JordiGelDVBMixed Bed $(250 \mathrm{~mm} \mathrm{A10} \mathrm{mm)} \mathrm{columns} \mathrm{and} \mathrm{refractive} \mathrm{detector,} \mathrm{and} \mathrm{THF}$ or chloroform as eluent $\left(1 \mathrm{~cm}^{3} / \mathrm{min}\right)$. The molecular weights were calibrated with polystyrene standards. Polymer viscosity was measured in N,N-dimethylformamide (at $30^{\circ} \mathrm{C}$ ) using a Ubbelohde viscometer (on Stabinger Viscometer SVM 3000).

DSC studies were performed in the temperature range from $-60^{\circ} \mathrm{C}$ to $+120^{\circ} \mathrm{C}$ using a Perkin Elmer Pyris 1 calorimeter at a heating rate of $20^{\circ} \mathrm{C} / \mathrm{min}$ for samples of 10 $25 \mathrm{mg}$ mass.

The obtained polyurethanes were extruded in the shape of threads (by Brabender extrusion machine). Fail stress $\left(\mathrm{Se}_{\mathrm{f}}\right)$, stress at $100 \%$ elongation $\left(\mathrm{Se}_{100}\right)$, stress at $200 \%$ elongation $\left(\mathrm{Se}_{200}\right)$, stress at $300 \%$ elongation $\left(\mathrm{Se}_{300}\right)$, elongation at break $\left(\mathrm{E}_{\mathrm{b}}\right)$, elongation (E), hardness (oIRH) of the samples were measured using an Zwick model 1445 tester. $\mathrm{Se}_{\mathrm{f}}, \mathrm{Se}_{100}, \mathrm{Se}_{200}, \mathrm{Se}_{300}, \mathrm{E}_{\mathrm{b}}$ were determined according to national standard PN-ISO 37:98. E and oIRH were determined by IPG "Stomil" methods.

\section{Acknowledgements}

We gratefully acknowledge the financial support of the Warsaw Medical University.

\section{References}

[1] Oertel, G. Polyurethane handbook (Munich: Hanser Publishers; 1994).

[2] Wirpsza, Z. Polyurethanes: chemistry, technology and application (Ellis Horwood/Prentice-Hall, London, 1993).

[3] Sobczak, M.; Olędzka, E.; Kołodziejski, W; Kuźmicz, R. Polimery 2007, 52, 411. 
[4] Poussard, L.; Burel, F.; Couvercelle, J.P.; Merhi, Y.; Tabrizian, M.; Bunel, C. Biomaterials 2004, 25, 3473.

[5] Wang, J.-H.; Yao, C.-H.; Chuang, W.-Y.; Young, T.-H. J Biomed. Mater. Res. 2000, 51, 761.

[6] Martin, D.J.; Poole Warren, L.A.; Gunatillake, P.A.; McCarthy, S.J.; Meijs, G.F.; Schindhelm, K. Biomaterials 2000, 21, 1021.

[7] Park, J.H.; Park, K.D.; Bae, Y.H. Biomaterials 1999, 20, 943.

[8] Górna, K.; Gogolewski, S. Polym. Degrad. Stab. 2002, 75, 113.

[9] Król, P. Progress in Materials Science 2007, 52, 915.

[10] Albertsson, A.C.; Varma, I.K. Biomacromolecules 2003, 4(6), 1466.

[11] Florjańczyk, Z.,; Plichta, A.; Sobczak, M. Polimer 2006, 47, 1081.

[12] He, F.; Li, S.; Garreau, H.; Vert, M.; Zhuo, R. Polymer 2005, 46, 12682.

[13] Martin, E.; Dubois, P.; Jerome, R. Macromolecules 2003, 36, 5934.

[14] Storey, R.F.; Sherman, J.W.; Macromolecules 2002, 35, 1504.

[15] Sanda, F.; Sanada, H.; Shibasaki, Y.; Endo, T. Macromolecules 2002, 35, 680.

[16] Connor, E.F.; Nyce, G.W.; Myers, M.; Moeck, A.; Hedrick, J.L. J. Am. Chem. Soc. 2002, 124, 914.

[17] Biela, T.; Duda, A.; Pasch, H.; Rode, K. J. Polym. Sci. Part A: Polym. Chem. 2005, 43, 6116.

[18] Kowalski, A.; Libiszowski, J.; Biela, T.; Cypryk, M.; Duda, A.; Penczek, S. Macromolecules 2004, 38, 8170.

[19] Biela, T.; Duda, A.; Rode, K.; Pasch, H. Polymer 2003, 44, 1851.

[20] Sobczak, M.; Olędzka, E.; Kołodziejski, W.L. J. Macromol. Sci. Pure and Appl. 2008, 10, 872.

[21] Sobczak, M.; Kołodziejski, W.L.; Nurzyńska, K. Molecules 2010, 15, 842. 